\title{
Possibilities of Digitalization and Service Design in the Development of Patient Adherence
}

\author{
DIÁNA NAGY* \\ *Corvinus University of Budapest, Department of Management Control, \\ diana.nagy5@stud.uni-corvinus.hu
}

DOI: 10.14267/978-963-503-867-1_05

\begin{abstract}
In parallel with the development of modern health systems and the growth of the welfare state, diseases have shifted towards chronic diseases. Today, instead of rapid-onset infections, most resources are focused on the long-term treatment of mostly lifelong chronic conditions. The condition for the effective use of therapies is to take the specified dose with the prescribed frequency and for the required period of time. If these parameters are met, we can talk about patient collaboration or adherence. For certain diseases and treatments, adherence is critically low. In the case of complex preparations to be taken several times a day, or diseases that do not cause serious, noticeable complaints, the initial number of patients treated is reduced to a fraction within a short time. As a result, economic harm is perceived not only by the patient but also by all those involved in the health care system, including pharmaceutical companies. However, the factors influencing patient collaboration vary widely. In order to achieve high adherence, the goal is to develop health services that coordinate the actors involved, the infrastructure, the communication, the material components to improve the user experience. As a user-centered methodology, service design can play a prominent role in the design of therapeutic services, contributing to the reduction of uncertainties in innovation processes. In my study, I assess the digital toolkit of patient education in Hungarian society. The aim is to explore digital tools and technologies that can contribute to the development of health awareness and education so that both science and the pharmaceutical and technology companies that exploit it can apply the results of research.
\end{abstract}

Keywords: digitalization, digital transformation, adherence

Funding: The author did not receive any grant or institutional support in relation to the study's preparation. 


\section{Introduction}

Knowledge of the concept of adherence is not new, but there have been few studies on the effectiveness, applicability, and success of therapeutic methods, especially in Hungary, so not only can research fill a gap, but it also provides innovative value to pharmaceutical companies and provides guidance to patients' needs in a broader understanding. However, the factors influencing patient collaboration vary widely. In addition to patient-dependent health status, factors dependent on therapy, socioeconomic, health, and care staff also affect the success of adherence (World Health Organization, 2003).

According to international data, about half of the patients remain on the prescribed therapy (World Health Organization, 2003), the data in Hungary are worse (Molnár, 2011). We would like to examine what kind of digital device and technology could help to increase patient adherence among the Hungarian population in different age groups and different disease groups. The re-exacerbation of the disease, resulting from the discontinuation of therapy after the asymptomatic period (exacerbation), has a significant financial impact: the treatment of outpatient exacerbations is two to three times the cost of proper maintenance therapy. Poor adherence may result in unjustified drug changes, adjunctive therapies, or dose escalation (Berzai, 2017; Molnár \& Dankó, 2010). In addition to the patient, the economic damage is felt by all those involved in the healthcare system, including pharmaceutical companies. Economic burdens attributable to quantified nonadherence result in $\$ 100$ billion in annual spending in the United States (Vermeire et al., 2001), but an estimate from 2011 puts the economic damage caused by a lack of patient cooperation at $\$ 310$ billion (Capgemini Consulting, 2011).

The aim of the research is to explore the possibilities of applying the service design methodology in the design and implementation of user-friendly and experience-based health services. The research provides an opportunity to evaluate the digital educational effectiveness aspect of patients. The significance of the problem is shown by the fact that only 20-50 percent of patients consider cooperation to be appropriate (Molnár, 2011), thus, the social value of the research is enhanced by the fact that the exploration of Hungarian adherence relations on the basis of data affecting a wide population, in as many therapeutic areas as possible, can greatly help the development and successful application of digitally supported, comprehensive, complex therapy management programs. 


\section{Theoretical background}

Thanks to the growing prevalence of digitalization in healthcare as well, the latest technologies are no longer available not only in healthcare institutions but also in our daily lives. The Covid epidemic has brought up to 5-8 years of progress in the digitalization of telemedicine and healthcare. These innovative solutions were already available on the market, but the pandemic has now forced their use (László, 2020). "Pharma digitalization facilitates the healthcare transformation. Pharma digitalization will help the pharma business become more patient-centric. Patients will gain more possibilities for better and cost-effective care outcomes." (Kemppainen \& Liikkanen, 2017).

You can choose from a wide range of different mobile device applications and devices equipped with sensors to measure and record your health data, whether it is related to blood sugar levels or ovulation forecast. What we measured by at-home self-monitoring programs, can be shared immediately with our health care professional, who can remotely monitor and intervene in the therapy in a much more convenient and cost-effective way for both parties. In addition, the existing medical device products can be improved with sensor and connectivity technologies to collect data for further care analytics and personalized therapy (Kemppainen \& Liikkanen, 2017). Moreover, it is now possible to find out about a health issue with the help of a specialist if required. By using the telemedicine service, the number of visits to the doctor can be reduced, waiting times can be avoided and the patient can get answers to his questions in a short time. It is also possible to detect digital biomarkers with high frequency, increasing the importance of health data reliability and digital diagnostics. Such tools may include but are not limited to, so-called wearables as smartwatches, smart bracelets, but also various medical devices, even those that are already operating with an application. The key is for the patient to choose from readily available mobile solutions. "Fluctuations in blood pressure can be linked to events in our lives, we will see how this value changes during sleep or stress events... This can lead to disease prevention. This is where today's "sickness" for patient care turns to "health" for health preservation and prevention." (Szombathelyi, 2020). Measurement of therapeutical adherence can similarly provide accurate information about the positive (or even unfavorable) effects of medication and related treatment on a disease.

Most organizations focus on products and delivery channels. Many resources of organizations (time, budget, logistics) are devoted to outputs to the customer and internal processes (including the experience of the organization's employees) are ignored while service design focuses on these internal processes. Service design enhances the user and employee experience by planning, coordinating, and optimizing the organization's operations to better support customer journeys (Gibbons, 2017). 
It should be noted that it would be easier to develop new products if the exact needs of the customers are well known. According to the World Health Organization (2003), this approach implies the need for patient-tailored interventions. People-centered methodologies, such as design thinking focuses on understanding people's need help to find the most appropriate solution for dedicated problems. First, according to this method, the problem is determined by customer compassion based on prototype generation and experimentation. During the testing process, the solution can be flexibly modified until the product or service is refined.

A way to improve on patient adherence is to reduce the frequency of dosing. Instead of daily or weekly oral dosage forms, monthly, quarterly, or annual dosage forms may be the solution. In addition to making dosing more modern and comfortable, another direction of drug development, aimed at improving therapeutic adherence, is the development of combination drugs to replace several tablets taken in parallel. More convenient delivery devices or easier-to-use medical devices can also improve patient collaboration in practice (Molnár, 2010).

It is also useful for the industry to collect medical devices and data from monitoring, which allows the creation of databases and registers, so we can also filter by disease groups. We can find out how a population produces health status differences according to geological location, so other decision-making mechanisms are needed, for which the system develops models based on the data, using MI algorithms. In the case of a fairly large database, it is possible to analyze the risk on the basis of evidence, to make decisions prepared for the doctor, but also to generate lifestyle suggestions.

\section{Methods}

The main goal of the research is to examine the digital tools of patient education in Hungarian society. Exploring digital tools and technologies that can contribute to the development of health awareness and education, monitoring and measuring therapy for various diseases, so that science as well as pharmaceutical and technology companies can apply the results of research (Papp-Zipernovszky et al., 2016). However, an important goal is to map adherence support solutions for different generations and to find best practices and technologies for each research cohort. There is a lack of such accurate research data in the literature, although it is particularly important how confidently and regularly how different generations of social groups would use such digital tools and solutions, on which healthcare can also build. The aim is also for the research to assess what solutions are currently available to reduce non-adherence and to what segment of society they reach. Examined by location and age, we can get an accurate picture of 
therapeutic adherence related to disease groups by collecting perceptions and therapeutic attitudes. With the analysis of persistence, the degree of cooperation between different diseases, countries, or groups of patients and the factors influencing it to become comparable. In the course of literature research, I first examine the international experience, with special regard to the Central and Eastern European region, and then with company and industry research, I continue to explore the background of the topic, fine-tune the research areas, and research questions. Expert and corporate interviews would be conducted using the method of semi-structured qualitative in-depth interviews, followed by data collection from population questionnaires, quantitative and qualitative data recording, and statistical data analysis. After disseminating the results obtained in this way, preparing case studies and providing feedback to the participants in the research. Summarizing company experiences, formulating proposals and action plans, the aim of which is to provide scientific and professional feedback to the participants in the research.

I evaluate the Hungarian population by participating in activities at a pharmaceutical company and using a questionnaire method. The series of events, already available in 82 cities, also includes free health screenings, counseling, sports programs, and interactive, motivational lectures. Furthermore, to assessing their own health status, visitors are encouraged to participate in support of local health institutions in addition to unnoticed deepening of contact with local professionals. Among other activities of the company, this program provides an opportunity to partially answer research questions, thus providing an excellent opportunity to study the therapeutic adherence habits of the population living in different parts of the country for a wide range of age groups. Questionnaire data collection allows the mapping of participants' attitudes to adherence along a comprehensive study of patient attitudes.

In addition to processing the literature and questionnaires, I would like to gather practical problems and questions through interviews with several experts and target groups that can help determine the effectiveness of adherence, especially the practices and tools used. In this, the literature left many questions open. 


\section{Results}

The design and execution of therapeutic processes play a key role in abandoning therapy. In order to achieve high adherence, the goal is to develop health services that coordinate the actors involved, the infrastructure, the communication, and the material components in order to improve the user experience. Moreover, in addition to patient care, these new solutions can also be used in the field of risk analysis in connection with epidemic data collection. A poorly designed service process can make life particularly difficult for patients with otherwise medical difficulties, which can further worsen adherence. As a usercentered methodology, service design can play a prominent role in the design of therapeutic services, contributing to the reduction of uncertainties in innovation processes.

\section{Discussion and recommendations}

The questions of the research highlight the shortcomings of the sector, and its results are thus suitable for influencing the innovation processes of the partner company and the whole sector, and in a broader sense for a positive effect on the preservation of the health of society. In addition to healthcare providers, the tangible results of the hypothesis testing have a value-creating effect for pharmaceutical companies as well, as it provides input for the development of more focused product and service innovations, as well as their usability in patient-centered lighting. Increasing therapeutic adherence is also reflected at the economic level, but its social benefits are indisputable. Improving health status, increasing age, fewer interventions; requires fewer long-term hospitalizations, thereby relieving the health care chain.

"Patient care data is the new source of innovation and competitiveness for the pharma companies as the real-world evidence. It is obvious that these market challenges and requirements can't be met with the current products, business models, and operations. Therefore, the pharma business transformation is inevitable which will lead to the digitalization of the pharma products, business models, operations and ultimately - the patient care" (Kemppainen \& Liikkanen, 2017).

The research fills a gap in several respects, so it contributes to the fine-tuning of service and product development processes with digital solutions, not only in Hungary but also internationally. Everything, that is done to improve therapy follow-up, has significant social value, as it directly increases the age of the population, improves the quality of life, and reduces the additional costs to the health care system arising from the treatment of worsening diseases. 


\section{References}

Berzai, E. (2017, November 28). A jó gyógyszer csak egy lépcsố a gyógyuláshoz vezető úton. Medicalonline.

http://medicalonline.hu/cikk/a_jo_gyogyszer_csak_egy_lepcso_a_gyogyulashoz_veze to_uton

Capgemini Consulting. (2011). Patient Adherence: The next Frontier in Patient Care, Vision \& Reality 9th Edition, Global Research Report.

László, P. (2020, December 8). Akár 8 éves lemaradást is ledolgozhatott az egészségügy egy év alatt, és a járványnak még nem látszik a vége [Audio podcast episode]. In G7 Podcast. https://g7.hu/podcast/20201208/akar-8-eves-lemaradast-is-ledolgozhatott-azegeszsegugy-egy-ev-alatt-es-a-jarvanynak-meg-nem-latszik-a-vege/

Molnár, M. P. (2010, October 16). Hogyan javítható a beteg-együttmúködés? Pharmaonline Adherencia Tudástár 6. http://pharmaonline.hu/cikk/hogyan_javithato_a_beteg_egyuttmukodes

Molnár, M. P. (2011, June 2). Beteg-együttmúködés és a háttérben meghúzódó tényezók. XIV. Betegbiztonsági Fórum.

Molnár, M. P., \& Dankó D. (2010, Április 9). A beteg-együttmúködés a terápiás siker záloga. Orvostovábbképzö Szemle, 17(4). http://otszonline.hu/cikk/a_beteg_egyuttmukodes_a_terapias_siker_zaloga

Papp-Zipernovszky, O., Náfrádi, L., Schulz, P. J., \& Csabai, M. (2016). „Hogy minden beteg megértse!" - Az egészségmúveltség (health literacy) mérése Magyarországon. Orvosi Hetilap, 157(23). https://doi.org/10.1556/650.2016.30498

Kemppainen, P., \& Liikkanen, S. (2017). Pharma Digitalisation: Challenges and opportunities in transforming the pharma industry. European Pharmaceutical Review.

https://www.europeanpharmaceuticalreview.com/article/51733/pharma-digitalisationchallenges/

Gibbons, S. (2017, July 9). Service Design 101. Nielsen Norman Group (NN/g). https://www.nngroup.com/articles/service-design-101/

Szombathelyi, Zs. (2020, April 2). Digitalizáció az egészségügyben: most fog csak robbanni igazán! Portfolio. https://www.portfolio.hu/gazdasag/20200402/digitalizacio-azegeszsegugyben-most-fog-csak-robbanni-igazan- 422586

Vermeire, E., Hearnshaw, H., van Royen, P., \& Denekens, J. (2001). Patient adherence to treatment: three decades of research. A comprehensive review. Journal of Clinical Pharmacy and Therapeutics, 26(5). https://doi.org/10.1046/j.1365-2710.2001.00363.x

World Health Organization. (2003). Adherence to long-term therapies: evidence for action. ISBN: 9241545992

https://www.who.int/chp/knowledge/publications/adherence_report/en/ 